\title{
Investigating Pronunciation Material Tasks and Method of Teaching in Sunrise Series 7-9
}

\author{
Pakhshan I. Hamad ${ }^{1}$, Dlakhshan Y. Othman², Himdad A. Muhammad ${ }^{3}$ \\ 1, 2, 3 Department of English Language, College of Basic Education, Salahaddin University- Erbil, Kurdistan Region, Iraq
}

\begin{abstract}
This study is an attempt to investigate pronunciation material and tasks and/or activities along with teaching methods in Sunrise 7-9 series adopted by the ministry of education in KRG to be taught in basic schools all over Kurdistan region of Iraq. The rationale of the study is the obvious deficiency of basic school students' performance, more specifically of student's pronunciation and speaking skill. Pronunciation is regarded as one of the basic components in learning English, hence conducting this study is deemed necessary. This paper focuses on investigating pronunciation material, tasks/exercises and teaching methods used from the teachers' and researchers' perspectives. To this end, a questionnaire was administered to 51 English teachers who have taught these books for at least three years in Basic Schools in Erbil city and an observation checklist was designed to observe 30 lesson periods of teachers. The data are analyzed through SPSS program to find out the frequencies, percentages, mean and standard deviation. The results reveal that most of the teachers are (not quite) satisfied with the pronunciation material, more than half of teachers are not satisfied with the tasks and exercises due to time and lack of equipment, almost none of the teachers use effective and suitable teaching methods and the sound files found within the teachers' book of the series. Based on the results, some new pronunciation material, new tasks, exercises, teaching strategies and also some recommendations are presented.
\end{abstract}

KEY WORDS: Material, Pronunciation, Sunrise, Tasks, Teaching Methods

\section{INTRODUCTION:}

To design a study program is not an easy straightforward task because it needs thorough planning and taking all aspects into consideration. Even though, the teachers who use and teach this program have been consulted at various phases of the program design, but knowing their views and perceptions concerning different aspects of the program is vital and crucial.

Sunrise is an English program designed by Macmillan company for Kurdistan region schools and kindergartens. It has been implemented since 2005 but it

Koya University Journal of Humanities and Social Sciences (KUJHSS), Volume 4, Issue 1, 2021.

Received 07 Sep 2020; Accepted 14 Oct 2020,

Regular research paper: Published 30 Jun 2021

Corresponding author's e-mail: hamid.al-ani@koyauniversity.org Copyright (C2021. Pakhshan I. Hamad, Dlakhshan Y. Othman, Himdad A. Muhammad, this is an open access article distributed under the Creative Commons Attribution License. was gradual, in other words each year one grade was implemented. By now, Sunrise program is being implemented and taught for 15 years and the teachers who have taught it are the best assets to get firsthand information on the shortcomings and pitfalls. Investigating all the parts of any program is a very difficult task. Therefore, this paper tackles only the pronunciation material, tasks and methods of teaching Sunrise series 7-9.

\section{THEORETICAL BACKGROUND \& PREVIOUS STUDIES}

English language teaching at Kurdistan region schools is based on Sunrise, a series of text books that teachers follow. However, teachers are to some extent have the right to pick corresponding materials to focus on or help students develop certain linguistic skills especially pronunciation. Nevertheless, it is to be stated that textbooks are the most significant teaching tools that teachers use since evaluations are totally based on the content of textbooks. 
Even though, there is pronunciation material in all the books of the series, there are activities and tasks in the pronunciation section but it is crucial to know the perception of teacher concerning these material and activities to find out whether they are sufficient, graded and supportive. More importantly, whether or not the material, activities and the teaching methods used affect student's oral performance and enable them to communicate. But, because all units do not have an activity focusing on pronunciation or because all the teachers do not do all the pronunciation exercises and they do not apply the teaching method suggested, it is very important to investigate the reasons and the underlying factors. Hence, pronunciation material, tasks and methods of teaching require close attention from the teachers' side and are likely to become fossilized if not taken care of at some point, and thus turn hard to eradicate (Littlewood, 1984).

Additionally, teachers who teach any specific program should know the extent of their learner's motivation. This is for making all the essential efforts to learn and practice pronunciation lively. Though students are the ones who are acquiring a new language and their perception and attitude of the significance of all aspects of the language is yet not formed, teachers must urge them to do that because it has for the most part been neglected in English as a foreign language (EFL) classroom (Kelly, 2000).

In this respect, Underhill (2005) and Griffiths (2011) have stated that teaching pronunciation has not been taken into great consideration by teachers. They agree that whenever pronunciation is studied in the classroom, specific pronunciation problems are needed to be dealt with that are observed in students' performance. Thus, it is significant for teachers to have well-designed plans to handle and manage pronunciation problems in an educational and pedagogical way. One of the most noticeable problems facing teaching pronunciation is what to teach about it, in other words what pronunciation material to teach. There are crucial pronunciation issues that FL teachers should pay due attention to. Firstly, they have to witness as many problems as the number of students in class. Secondly, teachers have to take caution about the mother tongue interference, in particular its phonetic system. Thirdly, teachers are required to have a sufficient information and background about variations. This study attempts to find out whether these challenges are the same from teachers' perspective or not.

If the materials related to pronunciation are not sufficient for instance, the teachers assigned to teach a specific grade or program have to add supplementary pronunciation explanations in their lesson plans which will support their students in grasping acceptable pronunciation for better and successful communication
(Griffiths, 2011). Also, teachers will "enable learners to surpass the threshold level so that their pronunciation will not detract from the ability to communicate" (CelceMurcia et al, 1996, p. 8).

As for previous studies on this topic, there are some previous works, but one of them is more relevant than others. Fars. N.M and Muhammad, HA (2020) conducted a study entitled " Investigating Productive Skills in Sunrise Series 7-9 from Kurdish EFL Teachers' Perspective" in which they discuss productive skills in Sunrise including speaking and writing. This study aims at investigating productive skills in Sunrise series 7-9 from Kurdish EFL Teachers Perspective. It focuses on teachers' perception on the material and activities that are found in Sunrise series 7-9. Productive skills include writing and speaking separate or integrative with each other and other skills. Though, teachers' view might have been taken into consideration prior to the implementation of Sunrise program in schools but their view and perception after more than ten years of the implementation of the program is much more important in order to have a better idea about the shortcomings and procedures required to fill them. This paper is a quantitative study and the data was collected through a close ended questionnaire administered to $170 \mathrm{EFL}$ teachers at the Centre Directorate of Education and Dashti Hawler directorate of education in ErbilKurdistan region of Iraq in the academic year 2019-2020. All the teachers had at least three years' experience in teaching Sunrise 7-9. The findings have indicated that productive skills are given their due attention in the program but for the implementation of the program, covering the material within the time period allocated for the lesson is still not satisfactory to the majority of the teachers. This is primarily attributed to large and crowded classes as it hinders using the suggested method and students practice time. The amount and length of productive skill activities are suitable to improve students both productive skills, namely speaking and writing if they are implemented.

The present paper, therefore, focuses only on pronunciation part of the program and it covers all aspects of pronunciation including material, tasks and exercises. In short, investigating issues such as pronunciation material, tasks and activities and methods of teaching from teachers' perspective and confirming these views through observation checklist by three researchers would be of great value because it will be an authentic unbiased investigation and the findings will be valid and reliable.

\section{SUNRISE PROGRAM}

Sunrise has thirteen books ( 1 pre-school level, 9 basic education levels, 3 secondary levels). The series of Sunrise consists of the Student Books, Activity Books, 
Teachers Books and audio CDs for each level as well as several additions for primary levels as flashcards, and posters. There is also a website which supplies information about Sunrise (www.Sunrisekurdistan.com).

The Sunrise course has a communicative approach, integrating listening, speaking, reading and writing with a clear focus on grammar structures. But whether, or not, the teachers adopt this approach during teaching is another issue. This study is an attempt to figure out the method of teaching used for teaching pronunciation material from teachers' perspective and from researchers' point of view through both study instruments.

At the end of each Student's Book there is a Wordlist which is like a small dictionary includes new vocabulary in English and their meaning in Kurdish for each level of the course. There is also Grammar Reference which provides fundamental meta-language for talking about grammar and analyzing it in another language and it is Kurdish language. In Student's Book there is also activity called Study Skills which provide students various techniques to improve students' learning and helping to acquire new vocabulary which leads to learner independence.

Sunrise (7-9) series is a vital stage to build on the efficiency of learning and to prepare students to preparatory stage. The beginning of each Student's Book starts with welcome unit which is revision of the previous materials or introducing new characters of the book. In Sunrise (7-9) series, there are both of the receptive which are listening, reading and productive skills which are writing and speaking. Usually, each unit includes four lessons and a review at the end of the unit. After studying certain activities in student's book, two or three activities from activity book has been specified to be done whether inside class as group work or as homework.

Sunrise 7 is designed to build on students' development and to progress. The main characteristics of this level are making learning fun through motivating topic-based units. Sunrise 7 components are Student's Book, Activity Book, Teacher's Book and audio CDs (two CDs each for one course). The Student's Book consists of welcome unit, seven other units and a farewell unit which only consists of three activities about goodbye from London.

\subsection{Sample Sunrise Analysis: (7-8-9)}

Each unit has a review lesson at the end to recycle and reinforce language. It has dramatized dialogues for students to act out and practice real language. It has a $\mathrm{CD}$ with dialogues and sound files to practice pronunciation and intonation.

\subsubsection{Sunrise Analysis: (7-8-9)}

The components of Sunrise are: Student's Book, Activity Book, Teacher's Book and Audio CD.

The Student's Book consists of units 1-7, each with four lessons, a review and an English-speaking world lesson. Lessons 1,2, and 3 are language lessons and 4 is an integrated skill lesson.

\subsection{Tables of Pronunciation Material/Tasks:}

In order to have a clearer picture of the pronunciation material and tasks in Sunrise series 7-9, taxonomy of the textbook units and lessons will be presented below:

TABLE 1

Pronunciation Material/Tasks in Sunrise Seven

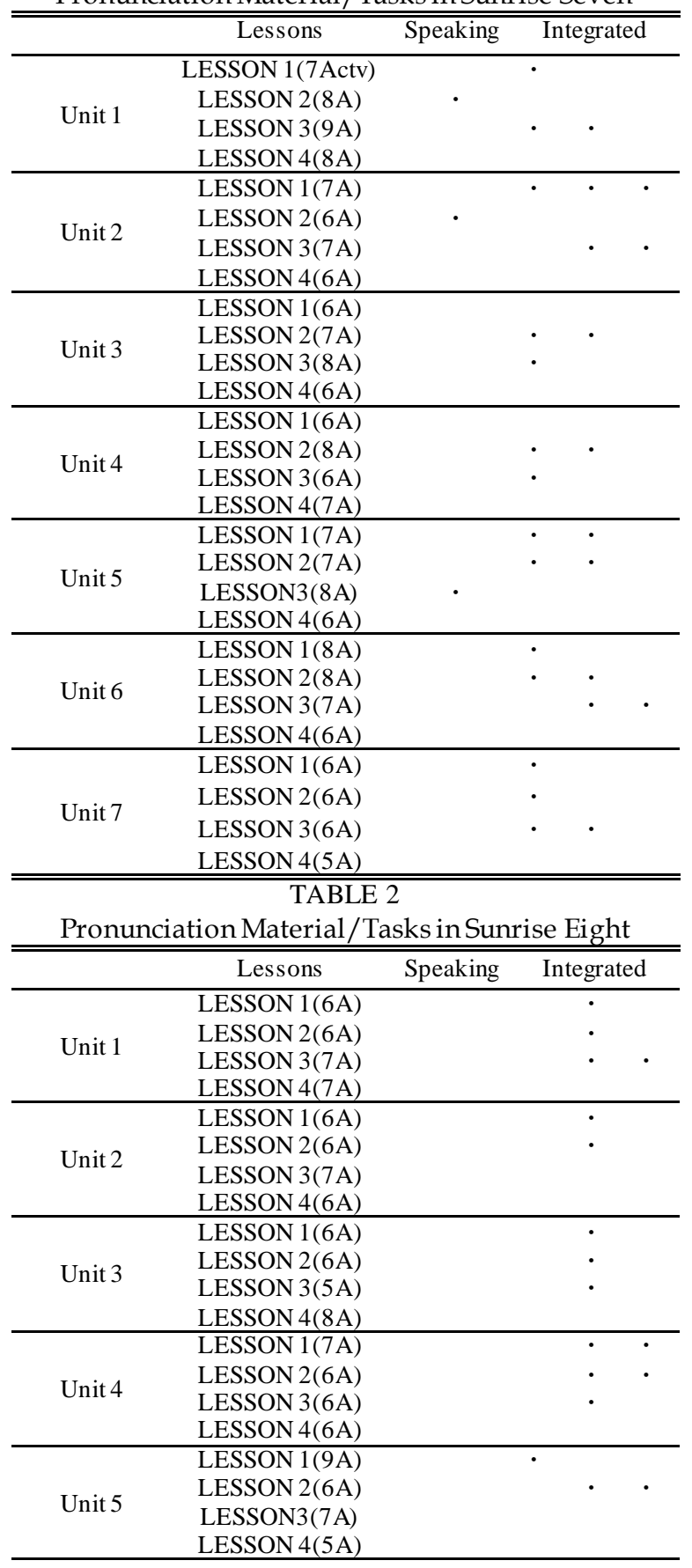




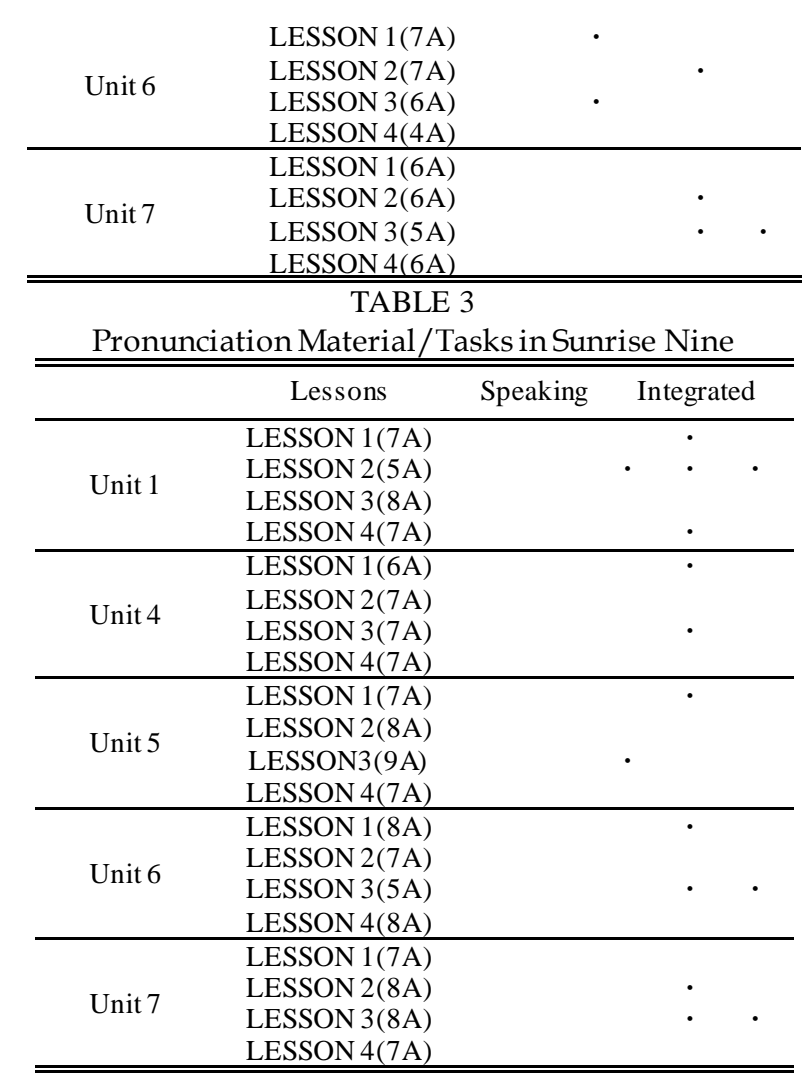

As noticed in the above table, the pronunciation material varies from one textbook to another, but all in all the quantity of pronunciation material compared to other skills and language areas is kind of balanced. Moreover, we notice that there are some specific tasks and activities which are allocated for pronunciation proper; yet there are many other activities and tasks where pronunciation is integrated into other skills such as listening and reading.

\section{METHODOLOGY AND RESEARCH DESIGN}

\subsection{Instruments}

In order to collect data for the study, two instruments have been used, namely a questionnaire and an observation checklist. The questionnaire consists of 28 items and was designed by the researchers to be administered to the EFL teachers who have taught Sunrise program for at least three years. It consists of three parts. Part one includes 12 items on the nature, quality and distribution of pronunciation material in Sunrise series 7-9. Part two includes 7 items related to the quantity and quality of the pronunciation tasks and activities. Part three contains 9 items to cover the issue of the methods of teaching used in teaching pronunciation. The second tool used to collect data was an observation checklist. It consists of 14 items related to the pronunciation material, tasks and activities and the methods of teaching actually employed by the teachers in order to confirm the data of the questionnaire.

\subsection{Participants}

For collecting authentic and reliable data, the questionnaire was administered to $51 \mathrm{EFL}$ teachers in Erbil, who have experience in teaching Sunrise 7-9 for at least three years.

The actual class observation was 30 full lesson periods conducted by the researchers of this study at 22 different schools.

The samples of the study were selected randomly from Erbil city schools for both the questionnaire and the observation.

\subsection{Methodology}

The paper adopts mixed quantitative-qualitative approach for the analysis of the data. The collected data, th were analyzed both quantitively and qualitatively. For the quantitative analysis Statistical Package of Social Sciences (SPSS) has been utilized to find out the percentage, the Mean and Standard Deviation. Some of the items in the observation checklist were analyzed qualitatively by the researchers.

\section{RESULTS AND DISCUSSION}

\subsection{Questionnaire}

This section presents the results and discussion in the light of the research questions and as follows:

The first study question reads: To what extent the pronunciation material, tasks and activities affect students' pronunciation performance?

Table (4) shows the mean values, standard deviation and percentage of the participants' perspective on the pronunciation materials in Sunrise7-9 series and to what extent they affect students' pronunciation deficiency in Kurdistan region of Iraq.

TABLE 4

Descriptive Analysis of The Participants' View on The Material

\begin{tabular}{|c|c|c|c|}
\hline Items & $\mathrm{N}$ & Mean & $\begin{array}{c}\text { Std. } \\
\text { Deviation }\end{array}$ \\
\hline $\begin{array}{l}\text { Does the pronunciation material found at Sunrise } \\
\text { enable the students to comprehend the English sound } \\
\text { system? }\end{array}$ & 51 & 3.71 & 0.981 \\
\hline $\begin{array}{l}\text { Are the pronunciation materials logically organized } \\
\text { according to students' levels? }\end{array}$ & 51 & 3.31 & 1.188 \\
\hline Do students like the pronunciation material? & 51 & 3.75 & 1.221 \\
\hline Is the pronunciation material too much? & 51 & 3.16 & 1.349 \\
\hline Is the pronunciation material too little? & 51 & 2.78 & 1.374 \\
\hline $\begin{array}{l}\text { Is the pronunciation material quantity enough for } \\
\text { students? }\end{array}$ & 51 & 3.41 & 1.114 \\
\hline $\begin{array}{l}\text { Do the students have difficulty in practicing the } \\
\text { pronunciation material? }\end{array}$ & 51 & 2.86 & 1.344 \\
\hline $\begin{array}{l}\text { Do the students have difficulty in producing single } \\
\text { sounds? }\end{array}$ & 51 & 2.59 & 1.301 \\
\hline Do the students have difficulty in producing words? & 51 & 2.69 & 1.084 \\
\hline Do the students have difficulty in producing stress? & 51 & 3.10 & 1.246 \\
\hline $\begin{array}{l}\text { Do the students have difficulty in producing weak } \\
\text { forms? }\end{array}$ & 51 & 2.90 & 1.104 \\
\hline
\end{tabular}


The results indicate that, despite of the logical arrangement of the pronunciation topics in Sunrise series $(M=3.71$, with $S D=0.981)$, the students have difficulty in comprehending and producing English sound system appropriately. The most prominent reason behind students' deficiency in pronunciation is due to the lack of interest and absence of willingness and/or motivation to the pronunciation topics $(M=3.75$, with the SD 1.221). In addition, pronunciation is the least favorite topic for teachers to address the classroom. This is also confirmed by the literature.

The results, also, show that the pronunciation quantity in Sunrise series7-9 are sufficient for the students to develop their pronunciation $(\mathrm{M}=3.41, \mathrm{SD}=1.114)$. However, Kurdish EFL students face difficulties in mastering the aspect of connected speech, such as stress $(\mathrm{M}=3.10, \mathrm{SD}=1.246)$ weak forms $(\mathrm{M}=2.90, \mathrm{SD}=1.104)$ and intonation $(\mathrm{M}=2.27, \mathrm{SD}=1.119)$ due to the absence of the aspects of connected speech in student's native language cause students' pronunciation deficiency. Furthermore, it is deduced that the dissimilarity between the suprasegmental features, stress and intonation, lead to a deep deficiency in the students' pronunciation. Pronunciation teachers' view points on the suitability of the pronunciation materials in the Sunrise series (7-9) are summarized in figure (1).

\section{FIGURE 1}

Descriptive Statistics of Teachers' Perspectives on The Pronunciation Materials

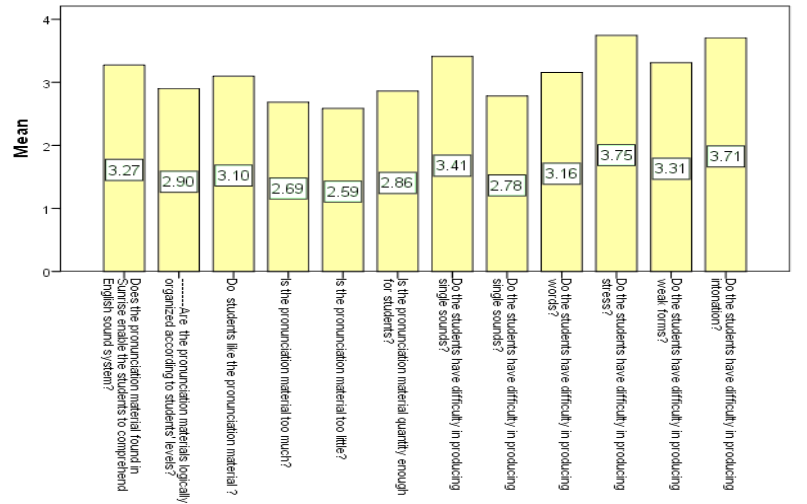

The above figure gives a clearer picture of the EFL teachers perception on the pronunciation material in general and certain aspects such as suprasegmental and aspects of connected speech, namely stress and intonation.

TABLE 5

Descriptive Analysis of The Participants' View on Tasks

\begin{tabular}{lrrr}
\hline \hline \multicolumn{1}{c}{ Items } & N Mean & $\begin{array}{c}\text { Std. } \\
\text { Deviation }\end{array}$ \\
\hline $\begin{array}{l}\text { Do the pronunciation tasks/exercises meet the learner's } \\
\text { needs for practicing the items they have been taught? }\end{array}$ & 3.39 & 0.806 \\
$\begin{array}{l}\text { Do the pronunciation tasks/exercise reinforce the items } \\
\text { that have been taught? }\end{array}$ & 51.07 & 1.168 \\
$\begin{array}{l}\text { Do the pronunciation tasks/ex ercises include } \\
\text { meaningful activities that enhance students' }\end{array}$ & 51 & 2.60 & 1.191 \\
communicative competence?
\end{tabular}

Are the pronunciation tasks/exercises too difficult for students?

Are the pronunciation tasks/exercises too easy for students?

$512.96 \quad 1.326$

$513.02 \quad 1.133$

Are the pronunciation tasks/exercises suitable to the level $513.09 \quad 1.230$ of students?

Do you add your own exercise(s) for teaching pronunciation items?

$\begin{array}{lll}51 & 2.92 \quad 1.324\end{array}$

The descriptive statistics in Table (5) indicate that suitable materials, for teaching pronunciation and the pronunciation instructions are appropriately emphasized in curricula and they meet students' needs for practicing the items. In addition, the tasks/exercises reinforce the items the students took from the previous units $(\mathrm{M}=3.39, \mathrm{SD}=0.806 ; \mathrm{M}=3.07, \mathrm{SD}=1.168)$. The participants also agree that the pronunciation tasks/exercises are suitable to the level of the students $(\mathrm{M}=3.09, \mathrm{SD}=1.230)$. Nevertheless, the suitability of the tasks and activities does not seem to have any visible effect on student pronunciation proficiency. The reason behind student's poor pronunciation is that the teachers never add their own exercise(s) in teaching pronunciation ( $\mathrm{M}=2.92, \mathrm{SD}=1.324)$. To overcome this deficiency the teachers, need to be involved in regular training courses in order to be familiarized with pronunciation tasks and activities included in the Sunrise series (7-9) and the related materials and activities should be constructed in a suitable way to make pronunciation learning much more fruitful.

\section{FIGURE 1}

Descriptive Statistics of Teachers' Perspectives on The Pronunciation Materials

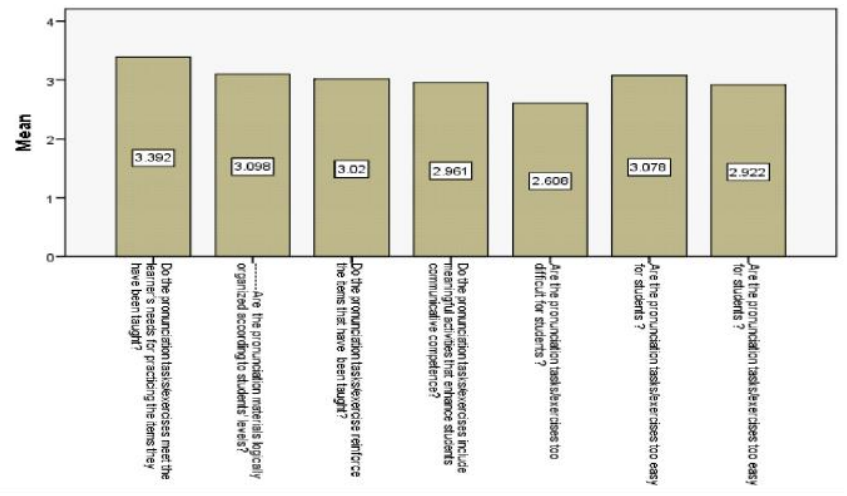

Figure (2) illustrates the mean points of participants' view on the expediency of the pronunciation tasks and activities in Sunrise series and to what extent the meet Kurdish EFL needs and interest.

TABLE 6

Descriptive Analysis of The Participants' View on Teaching Methods

\begin{tabular}{lcccc}
\hline \hline \multicolumn{1}{c}{ Items } & $\mathrm{N}$ & Mean & $\begin{array}{c}\text { Std. } \\
\text { Deviation }\end{array}$ \\
\hline $\begin{array}{l}\text { Do you use one teaching method for teaching } \\
\text { pronunciation items? }\end{array}$ & 51 & 3.22 & 1.363 \\
$\begin{array}{l}\text { Do you face difficulty in teaching pronunciation } \\
\text { items? }\end{array}$ & 51 & 3.24 & 1.168
\end{tabular}




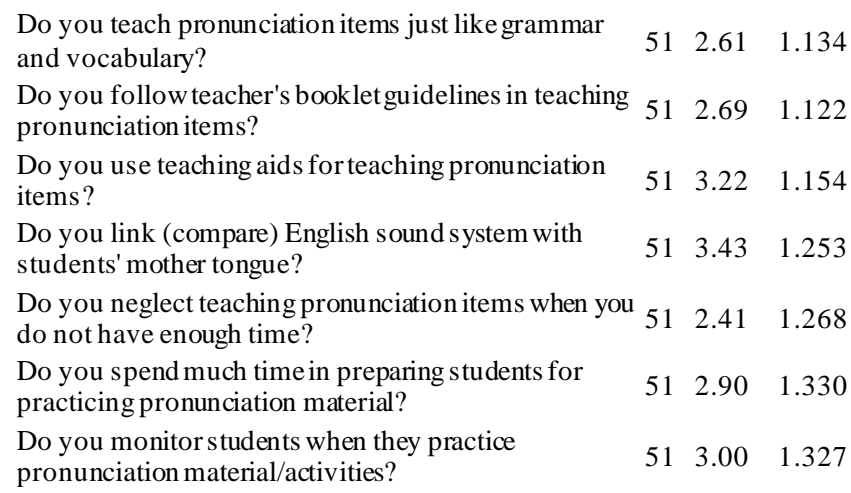

The results, on the table (6) show that the lack of an effective pronunciation teaching method $(\mathrm{M}=3.22$, $\mathrm{SD}=1.36$ ) and suitable pronunciation curriculum are considered as effective factors in learning English language sound system. Concerning the comparison between Kurdish and English phonology, the results of the study reveal that one of the problematic issues teachers face in teaching pronunciation is that they rarely try to find a connection between segmental and prosodic feature in students' native and the target language $(M=3.43, S D=1.253)$. The lack of suitable use teaching aids for teaching pronunciation items $(\mathrm{M}=3.22$, $\mathrm{SD}=1.154)$ and the neglect to monitor the students in practicing pronunciation material/activities $(M=3.00$, $\mathrm{SD}=1.327$ ) also affect pronunciation development in the pronunciation classes. Resulting from the mentioned facts, it is deduced that the EFL pronunciation teachers are inadequately prepared to teach pronunciation, especially novice teachers who are less experienced in this special field of teaching. As a consequence, they need to be acquainted with suitable phonetic training courses and pronunciation strategies and they must practice their work carefully. Figure 3 illustrates the mean point of each question from the participants' viewpoints.

\section{FIGURE 3}

Descriptive Statistics of Teachers' Perspectives on The Pronunciation Teaching Methods

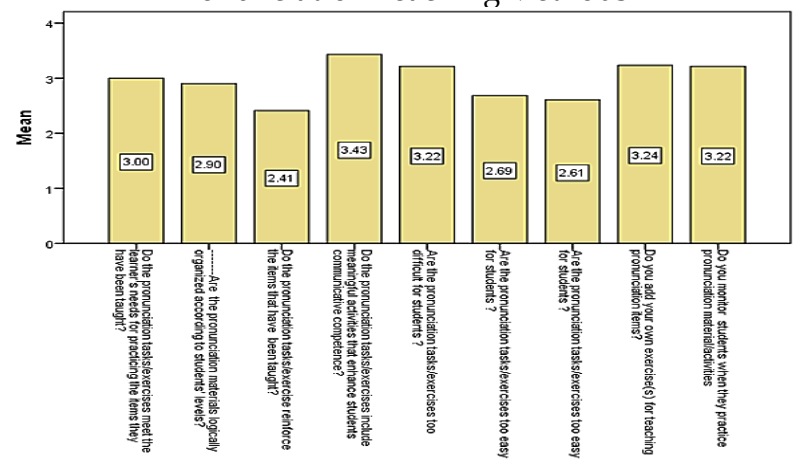

\subsection{Observation Checklist Analysis}

The second tool in this study, as noted earlier, is an observation checklist. It is used to investigate to what extent the effect of pronunciation material, tasks and activities are reflected in Kurdish EFL teachers' classes during teaching pronunciation.

The results obtained from the observations of 15 English lesson periods out of $30(50 \%)$ show that the pronunciation material, tasks and methods helped the students to comprehend the English sound system easily, whereas, in 13 lesson periods $(43.3 \%)$, the observers found that the materials, tasks and methods needed to be improved to assist the students to comprehend the English sound system. The results, also, show that only in 3 lesson periods $(7 \%)$ the materials and tasks had no effect on students' recognition of the English sound system.

The researchers found that the pronunciation materials in the Sunrise series7-9, in $(60 \%)$ of the observed classes, are logically organized and suit Kurdish EFL students' level, while in (40\%) English classes, the pronunciation materials needed to be improved to fit student's level. Concerning the amount of the pronunciation material in the Sunrise series, the researchers found out that in 8 English classes out of 30 $(26.6 \%)$ the materials were sufficient for the students to develop their pronunciation abilities, and in 6 classes $(20 \%)$ the pronunciation materials need to be increased. Moreover, the pronunciation material, in 16 classes (53\%), are not enough to develop Kurdish EFL students' pronunciation performance.

To identify the extent to which the teacher followed the teacher's book guide for teaching pronunciation, only 3 teachers $(10 \%)$ followed the teaching during explaining the pronunciation material and doing the tasks, whereas 27 teachers $(90 \%)$ did not rely on the teachers' guide to teach the pronunciation material, tasks, and activities.

During the observation, it was observed that 17 English teachers out of 30 (56\%) taught English segmental and supra-segmental features without comparing them to Kurdish segmental and suprasegmental features, while in 13 lesson periods $(44 \%)$ the teachers discussed some sounds in relation to the same sound in the student's native language very superficially. It was also observed that 22 teachers out of $30(73 \%)$ neglected the pronunciation tasks and activities when they are short of time, whilst only 8 teachers out of $30(26 \%)$ focused on the pronunciation tasks and activities.

To point out to what extent the EFL teachers prepare the students to practice the pronunciation tasks, it was witnessed that only 3 teachers $(10 \%)$ spent time to prepare the students for the pronunciation tasks, while17 of them (56\%) needed to do more practice. However, 10 teachers out of $30(30 \%)$ asked the students to do the tasks and activities without giving any 
clarifications or clear instruction. During the observation phases, it was found that the tasks and activities in the Sunrise series are easy enough to fit the students' level in $(30 \%)$ of the English classes. Whereas, they need to be improved to fit the student's level in18 English class $(60 \%)$, and it is too difficult for the students based on the results obtained in only 2 English classes (6\%).

The EFL teachers in 20 English classes out of thirty $(67 \%)$ used only one method for teaching the pronunciation topics. However, 10 teachers $(33 \%)$ tried to integrate different teaching methods to present the pronunciation materials in their classes.

Finally, the majority of the teachers $(87 \%)$ were satisfied with the tasks and activities that are found in the books to teach the pronunciation materials, whereas, only $4(13 \%)$ teachers add new tasks, activities to simplify the topics to their students.

\section{CONCLUSIONS}

Based on the analysis of the data collected through both instruments, the following findings are drawn:

Concerning pronunciation material, most of the teachers believed that the material is sufficient, meets the needs of the students and affects student's communicative performance, while from the researcher's point of view pronunciation material in Sunrise series 7-9 need some supplementary material especially some material that focuses on the aspects of connected speech and suprasegmental features along with creating some kind of comparison with the students' mother tongue.

As far as the pronunciation tasks and activities in Sunrise series 7-9 from teachers' perspective, the tasks are easy and graded, they fit students' level and lead to progress in student's pronunciation. From the researchers' perspective this is true to a good extent but some tasks and activities need to be added in order to provide more opportunity for practice especially in areas in which students have problems.

As for the teaching methods, the researchers' observation has also confirmed that most of the teachers used one teaching method for teaching the pronunciation material, they did not use teaching aids and make good preparation before teaching and doing the activities.

\section{REFERENCES}

Basurto Santos, N. M., \& Busseniers, P. (2012). Investigating English language classrooms in Mexican schools: The issue of ent ry and access. Porta Linguarum, 17(1), 95-109.

Celce-Murcia, M., Brinton, D. M., \& Goodwin, J. M. (1996). Tea ching pronunciation: A reference for teachers of English speakers of other languages. New York, NY: Cambridge University Press.

Da Silva, V. (2012). Integrating pronunciation activities in Brazilian EFL classrooms. PLE Pensar Línguas Estrategeiras, 1(1). Retrieved from:

http://www.ucs.br/etc/revistas/index.php/ple/article/viewFil e/1433/1087 [Accessed 13Jan. 2020].

Dalton, C., \& Seidlhofer, B. (1994). Pronunciation. Oxford, UK: Oxford University.

Davies, M. B. (2007). Doing a successful research project: Using qualitative or quantitative methods. Basingstoke, UK: Palgra ve Macmillan.

Fars, NM\& Muhammad,HA (2020) 'Investigating Productive Skills in Sunrise Series 7-9 from Kurdish EFL Teachers' Perspective', Asian EFL Journal Research Articles, Volume 27, Issue No.2.3 April 2020 .

Garten-Sprenger, Judy, Philip P. Mclevr, N. (2006) Sunrise St ud ents' Book, Macmillan Education. (www.Sunrisekurdistan.com). [Accessed 18 Jan. 2020]

Griffiths, B. (2011). Integrating pronunciation into classroom activities. British Council \& BBC. Retrieved from http:/ / www.teachingenglish.org.uk/articles/integratingpronunciation-classroom-activities [Accessed 13 Jan. 2020]

Hedge, T. (2000). Teaching and learning in the language classroom. Oxford, UK: Oxford University Press. http://www.ucs.br/etc/revistas/index.php/ple/article/viewFil e/1433/1087 [Accessed 20Jan. 2020]

Kelly, G. (2000). How to teach pronunciation. Harlow, UK: Longman.

Littlewood, W. (1984). Foreign and second language learning: Language acquisition research and its implications for the classroom. Cambridge, UK: Cambridge University Press.

Underhill, A. (2005). Sound foundations: Learning and teaching pronunciation (2nd ed.). Oxford, UK: Macmillan. 